\title{
EFFECTS AND FATE OF HUMAN SERUM ALBUMIN ADMINISTERED INTRAVENOUSLY AND ORALLY TO PREMATURE INFANTS 1, 2
}

\author{
By CLEMENT A. SMITH, KENNETH G. PHILLIPS, ANd ROBERT O. ROTH \\ (From the Departments of Pediatrics and Obstetrics, Harvard Medical School; the Department \\ of Maternal and Child Health, Harvard School of Public Health; the Research \\ Laboratories of the Boston Lying-in Hospital, and the Infants' Hospital \\ of The Children's Medical Center, Boston, Mass.)
}

(Received for publication June 30, 1949)

Premature birth is usually accompanied by a low serum protein concentration $(1,2)$. Several investigators have found the globulin concentration to be relatively lower than the albumin fraction $(3,4)$, but all agree that the infants who are born most prematurely tend to have the lowest concentration of serum proteins, and, further, that the protein levels may fall even lower after birth, and rise only slowly during succeeding months.

The investigation reported here was stimulated by the report of McMurray, Roe, and Sweet (1) that repeated intravenous injections of human serum albumin resulted in elevation of serum albumin concentration, more rapid gain in weight, and a reduction of morbidity and mortality.

\section{PROCEDURE AND METHODS}

The general distribution of 71 babies studied is set out in Table I. Thirty-eight were in the Premature Nursery of the Boston Lying-in Hospital and 33 in the Premature Nursery of the Infants' Hospital. Two sub-groups receiving intravenous albumin consisted of 13 infants each, so that a total of 26 received albumin by vein; a group of 18 received albumin orally, and the controls numbered 27. The group receiving oral albumin was smaller than the others since it soon became apparent that their clinical progress and laboratory measurements did not differ from those of the controls; thereafter no more infants were given albumin by mouth. Because the length of hospital stay, which determined the number of albumin injections or feedings, varied inversely with weight at birth every attempt was made to preserve the same range of birth weights in each group. Table I indicates the fair degree

\footnotetext{
1 Supported in part by a grant from the Nutrition Foundation and by funds provided by an anonymous donor for research in the Department of Obstetrics, Harvard Medical School.

2 The serum albumin used in these studies was prepared by the American Red Cross from blood which it had collected from voluntary donors. The conclusions are those of the authors and do not necessarily reflect the policy of the National Blood Program of the American Red Cross.
}

of success achieved. In all comparisons of results, the groups were analyzed by birth weight so as further to avoid errors of interpretation.

The general supervision of all infants in both nurseries was under the same house and visiting staffs; if complications developed the diagnoses were made by those in clinical charge and simply recorded by the present authors. As a general rule, food consisted of human milk during the first two to six weeks after birth (the smaller infants being kept on human milk for the longer periods), and followed by a standard evaporated milk, corn syrup, and water formula. Feedings were accompanied by a standard regimen of accessory food substances. Intakes were kept at approximately 65 cals./lb. (144/kg.) per day in all infants.

During a period of ten months all infants in our two premature nurseries were utilized for this study, provided they were in reasonably good condition at the age of five days. Besides the usual physical examinations and biweekly weighings routinely performed, measurements of serum total protein, serum albumin (in 58 of the 71 infants), erythrocyte count, and hemoglobin concentration were made on the fifth day of life and at ten-day intervals thereafter until discharge from the hospital. These measurements were finally repeated upon as many of the infants as could be brought back three to four weeks later, so that any subsequent effects of albumin administration might be evaluated. Except for some of the serial hematocrit determinations, all laboratory measurements were performed upon samples obtained at least three days after the previous administration of albumin. This differed from the schedule of McMurray and her colleagues (1) who used samples drawn two hours after albumin was injected.

Serum total protein and albumin were measured by Kingsley's modification (5) of the method of Howe (6), and hemoglobin concentration of the blood by Evelyn photoelectric colorimeter. Samples for these measurements were obtained from capillary blood from a deep heel prick. For the nitrogen balance studies only male infants were used; stools were collected upon cellulose napkins, and urine was accumulated under thymol-toluene by means of a funnel-shaped tube fitted over the penis. Stool nitrogen was analyzed by standard macro-Kjeldahl method, urine nitrogen either by Nesslerization or by macro-Kjeldahl, and food nitrogen by macro-Kjeldahl.

The concentrated human serum albumin (salt-poor) was the standard 25 per cent solution (Lot numbers 379 
TABLE I

General subdivision of 71 infants studied

\begin{tabular}{|c|c|c|c|c|c|}
\hline \multirow[b]{3}{*}{ Number of infants } & \multicolumn{5}{|c|}{ Administration of albumin } \\
\hline & \multicolumn{2}{|c|}{ Intravenously } & \multirow{2}{*}{ 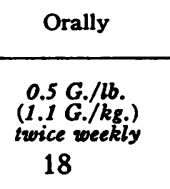 } & \multirow{2}{*}{$\begin{array}{c}\text { None (controls) } \\
27\end{array}$} & \multirow{2}{*}{$\begin{array}{c}\text { Total group } \\
71\end{array}$} \\
\hline & 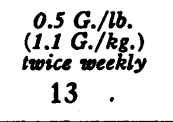 & $\begin{array}{l}0.75 \mathrm{G} . / \mathrm{lb} . \\
(1.6 \mathrm{G} . \mathrm{kg}) \\
\text { twice weeckly } \\
13\end{array}$ & & & \\
\hline $\begin{array}{l}\text { B.L.-i. Nursery } \\
\text { C.H. Nursery }\end{array}$ & $\begin{array}{l}7 \\
6\end{array}$ & $\begin{array}{l}7 \\
6\end{array}$ & $\begin{array}{r}10 \\
8\end{array}$ & $\begin{array}{l}14 \\
13\end{array}$ & $\begin{array}{l}38 \\
33\end{array}$ \\
\hline $\begin{array}{l}\text { Birth weight: } \\
\qquad \begin{array}{l}4-5 \mathrm{lb} . \\
(1.82-2.26 \mathrm{~kg} .)\end{array}\end{array}$ & 7 & 7 & 7 & 13 & 34 \\
\hline$(1.36-1.82 \mathrm{~kg})$. & 4 & 4 & 7 & 9 & 24 \\
\hline$(<1.36 \mathrm{lkg})$. & 2 & 2 & 4 & 5 & 13 \\
\hline Average birth weight & $\begin{array}{c}3 \mathrm{lb} .13 \mathrm{oz} . \\
(1.72 \mathrm{~kg} .)\end{array}$ & $\begin{array}{c}3 \mathrm{lb} .12 \mathrm{oz} . \\
(1.7 \mathrm{~kg} .)\end{array}$ & $\begin{array}{c}3 \mathrm{lb} .10 \mathrm{oz} . \\
(1.66 \mathrm{~kg} .)\end{array}$ & $\begin{array}{c}3 \mathrm{lb} .12 \mathrm{oz} . \\
(1.7 \mathrm{~kg} .)\end{array}$ & $\begin{array}{c}3 \mathrm{lb} .12 \mathrm{oz} \\
(1.69 \mathrm{~kg} .)\end{array}$ \\
\hline $\begin{array}{l}\text { Total amount of albumin given } \\
\text { (average) }\end{array}$ & $17 \mathrm{G}$. & $27 \mathrm{G}$. & $19 \mathrm{G}$. & & \\
\hline Number re-examined after discharge & 7 & 7 & 7 & 15 & 36 \\
\hline
\end{tabular}

R2 and R4) kindly furnished for this research by the American Red Cross. This was given intravenously into a scalp vein or added to the early gavage or later bottle feedings twice weekly, in the dosages presented in Table I. The first dose was usually administered five or six days after birth. Follow-up by letter, telephone, or visit five months or more after the last injection has indicated that, as was to be expected with the standard albumin subjected to heat treatment at $60^{\circ} \mathrm{C}$. for ten hours, no infant developed any evidence of late icterus.

\section{Effects of albumin injection and ingestion}

Figure 1 shows that although there was a considerable scatter of individual values, the infants of lower birth weight had slightly lower average concentrations of serum total protein. In all weight groups, those receiving albumin intravenously tended to maintain more constant levels of serum protein than either those receiving albumin orally or the controls, who showed progressive declines as they grew older.

Figure 2 presents the trend of average serum total protein and albumin in $\mathbf{5 8}$ infants upon whom both these measurements were made. The dots representing individual measurements are omitted, and the scale used for Figure 1 has been doubled so that differences are more easily appreciated. It is apparent that infants of both sub-groups re- ceiving intravenous albumin maintained slightly higher protein and albumin levels than did either the recipients of oral albumin or the controls. Repeated injections of albumin produced a slight but progressive elevation of serum albumin. Since the corresponding total protein concentrations neither rose nor fell significantly, the net effect in certain groups was a tendency to diminution of the globulin fractions. This may have been the result of plasma dilution though the inferences from hematocrit data would make that seem unlikely. Blood volume was not measured. No consistent difference was associated with the different dosages of albumin. Table II presents the average serum protein concentrations at approximate dates of discharge and thus at the conclusion of albumin administration.

Since many of the infants went home to towns at some distance from Boston, blood samples after discharge were obtained from only about half of the total number. The course of serum protein levels during approximately three weeks after discharge was, nevertheless, quite uniform, and is presented in Figure 3. It will be observed that whereas there was a rather prompt decline in the serum total protein and albumin concentrations of 


\section{SERUM TOTAL PROTEINS (G./100 CC.)}
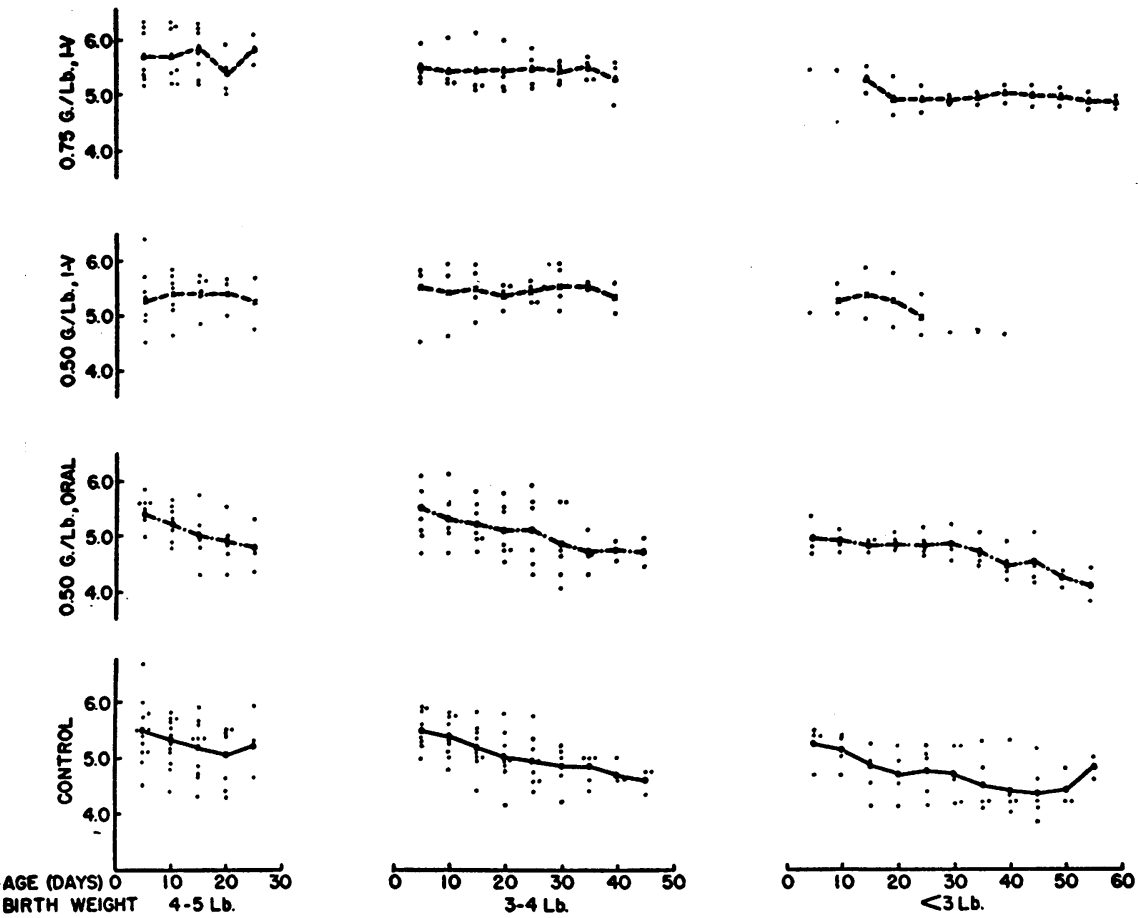

Fig. 1. Individual Values and Averages of Repeated Measurements of Serum Total Proteins in 71 Premature Infants

Arranged vertically in terms of albumin dosage and route of administration; horizontally in terms of birth weights of infants.

the infants who had received intravenous albumin, the serum protein and albumin levels of the oral recipients and controls subsequently rose instead of declining. As a result, the ultimate values were almost identical whether the infants had received albumin or not.
Although as stated above all infants appeared to be in satisfactory condition at the beginning of observations, 11 , described in Table III, developed intercurrent illness or untoward symptoms during the study, and there was one death. The separate groups of Table III are numerically so

TABLE II

Average total protein and albumin content of serum at discharge (58 infants)

\begin{tabular}{|c|c|c|c|c|c|c|}
\hline \multirow{2}{*}{ Birth weight } & \multirow{2}{*}{$\begin{array}{l}\text { Approximate } \\
\text { age at } \\
\text { discharge } \\
\text { (days) }\end{array}$} & \multirow{2}{*}{$\begin{array}{l}\text { Albumin } \\
\text { administered by: }\end{array}$} & \multirow{2}{*}{$\begin{array}{c}\text { Number of } \\
\text { infants }\end{array}$} & \multicolumn{3}{|c|}{ Protein at discharge $(G . / 100 c c)}$. \\
\hline & & & & $\begin{array}{l}\text { Serum total } \\
\text { protein }\end{array}$ & $\begin{array}{c}\text { Serum } \\
\text { albumin }\end{array}$ & $\begin{array}{l}\text { Difference } \\
\text { (globulin) }\end{array}$ \\
\hline $\begin{array}{c}4-5 \mathrm{lb} . \\
(1.82-2.26 \mathrm{~kg} .)\end{array}$ & 25 & $\begin{array}{l}\text { Injection } \\
\text { Ingestion } \\
\text { None }\end{array}$ & $\begin{array}{r}11 \\
5 \\
10\end{array}$ & $\begin{array}{l}5.5 \\
4.8 \\
5.2\end{array}$ & $\begin{array}{l}4.54 \\
3.7 \\
3.9\end{array}$ & $\begin{array}{l}0.96 \\
1.1 \\
1.3\end{array}$ \\
\hline $\begin{array}{c}3-4 \mathrm{lb} . \\
(1.36-1.82 \mathrm{~kg} .)\end{array}$ & 40 & $\begin{array}{l}\text { Injection } \\
\text { Ingestion } \\
\text { None }\end{array}$ & $\begin{array}{l}6 \\
7 \\
8\end{array}$ & $\begin{array}{l}5.3 \\
4.75 \\
4.7\end{array}$ & $\begin{array}{l}4.17 \\
3.75 \\
3.6\end{array}$ & $\begin{array}{l}1.13 \\
1.00 \\
1.10\end{array}$ \\
\hline $\begin{array}{c}<3 \mathrm{lb} . \\
(<1.36 \mathrm{~kg} .)\end{array}$ & 40 & $\begin{array}{l}\text { Injection } \\
\text { Ingestion } \\
\text { None }\end{array}$ & $\begin{array}{l}3 \\
4 \\
4\end{array}$ & $\begin{array}{l}4.7 \\
4.5 \\
4.4\end{array}$ & $\begin{array}{l}4.05 \\
3.6 \\
3.6\end{array}$ & $\begin{array}{l}0.72 \\
0.9 \\
0.8\end{array}$ \\
\hline
\end{tabular}


TABLE III

Complications

\begin{tabular}{|c|c|c|c|c|c|c|}
\hline Albumin dose & Number & & h we & & $\begin{array}{l}\text { Albumin re- } \\
\text { ceived before }\end{array}$ & Complication and remarks \\
\hline $\begin{array}{l}\text { G./lb. } \\
0.5 \\
\text { (I-V.) }\end{array}$ & $\begin{array}{l}1 \\
2 \\
3 \\
4\end{array}$ & $\begin{array}{l}2 b . \\
2, \\
3, \\
3, \\
2,\end{array}$ & $\begin{array}{r}08 . \\
4 \\
5 \\
5 \\
12\end{array}$ & $\begin{array}{l}\text { kg. } \\
(1.025) \\
(1.5) \\
(1.5) \\
(1.25)\end{array}$ & $\begin{array}{l}7.5 \mathrm{G} . \\
14.5 \mathrm{G} . \\
24.5 \mathrm{G} . \\
20.0 \mathrm{G} \text {. }\end{array}$ & $\begin{array}{l}\text { Aspiration pneumonia at } 39 \text { days-death. } \\
\text { Diarrheal disease at } 30 \text { days; gradual recovery. } \\
\text { Diarrheal disease at } 42 \text { days; gradual recovery; } \\
\text { no contact with preceding infant. } \\
\text { Edema from } 42 \text { nd to } 52 \mathrm{nd} \text { day, with serum } \\
\text { protein } 4.5 \mathrm{G} \text {. and albumin } 4.0 \mathrm{G} \text {. at onset. }\end{array}$ \\
\hline $\begin{array}{l}0.75 \\
(\mathrm{I}-\mathrm{V} .)\end{array}$ & $\begin{array}{l}5 \\
6\end{array}$ & $\begin{array}{l}2, \\
2,\end{array}$ & $\begin{array}{l}2 \\
0\end{array}$ & $\begin{array}{l}(0.97) \\
(0.91)\end{array}$ & $\begin{array}{l}6.9 \mathrm{G} . \\
24.0 \mathrm{G} .\end{array}$ & $\begin{array}{l}\text { Unexplained distension and vomiting, } 25 \text { th to } \\
28 \text { th day. } \\
\text { Edema, } 55 \text { th to } 60 \text { th day, with serum protein } \\
4.7 \mathrm{G} \text {. and albumin } 3.8 \mathrm{G} \text {. at onset. }\end{array}$ \\
\hline
\end{tabular}

\begin{tabular}{|c|c|c|c|c|c|c|}
\hline $\begin{array}{l}0.5 \\
\text { (Oral) }\end{array}$ & $\begin{array}{l}1 \\
2\end{array}$ & $\begin{array}{l}4, \\
2,\end{array}$ & $\begin{array}{l}2 \\
7\end{array}$ & $\begin{array}{l}(1.875) \\
(1.1)\end{array}$ & $\begin{array}{l}12.0 \mathrm{G} . \\
21.0 \mathrm{G} .\end{array}$ & $\begin{array}{l}\text { Diarrheal disease at } 23 \text { rd day. } \\
\text { Edema, } 48 \text { th to } 58 \text { th day, serum protein_4.2- } \\
4.5 \mathrm{G} \text {., albumin } 3.5-3.9 \mathrm{G} \text {. }\end{array}$ \\
\hline
\end{tabular}

(Sixteen, or 88 per cent, remained in good condition)

\begin{tabular}{|c|c|c|c|c|c|c|}
\hline None & $\begin{array}{l}1 \\
2 \\
3\end{array}$ & $\begin{array}{l}3, \\
2, \\
2, \\
\text { (T }\end{array}$ & $\begin{array}{r}15 \\
9 \\
3\end{array}$ & $\begin{array}{l}(1.79) \\
(1.16) \\
(1.0)\end{array}$ & $\begin{array}{l}- \\
-\end{array}$ & $\begin{array}{l}\text { Mild diarrhea and questionable pneumonia, } \\
30 \text { th to } 35 \text { th day. } \\
\text { Edema, 45th to } 50 \text { th day; serum protein } 4.5- \\
4.7 \mathrm{G} . \text { albumin } 3.3-3.9 \mathrm{G} \text {. } \\
\text { Edema, 50th to } 60 \text { th day; serum protein } 4.2 \\
\text { G., albumin } 3.6 \mathrm{G} \text {. } \\
\text { good condition) }\end{array}$ \\
\hline
\end{tabular}

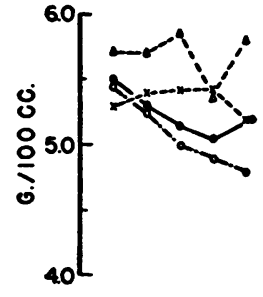

$\int_{30}^{50}$

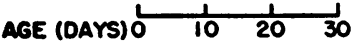

BARTH WEIGHT 4-5 Lb.

\section{SERUM TOTAL PROTEINS \\ (AVERAGES)}

\section{ALBUMW GIVEM

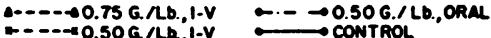
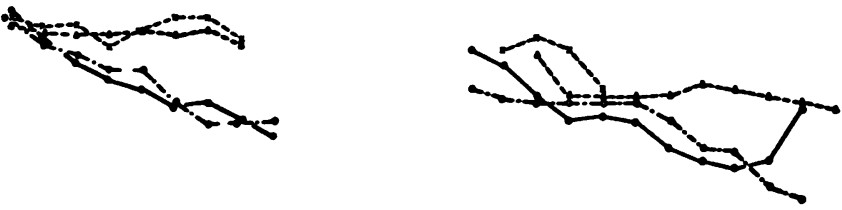

SERUM ALBUMIN

(AVERAGES)
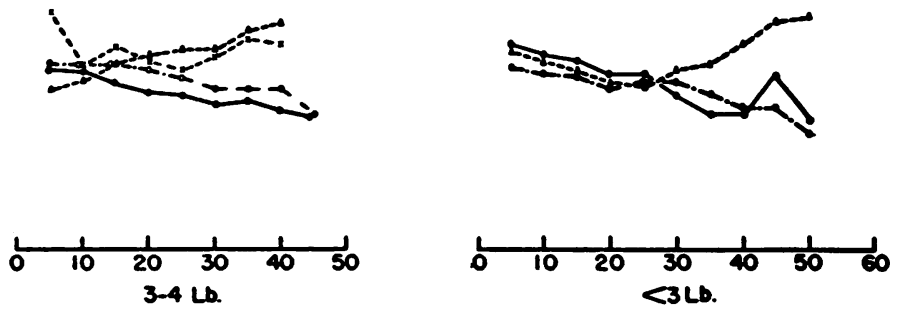

Fig. 2. Course of Averages of Serum Total Protems and Albumin Measurements in 58 Infaxts 


\section{COURSE OF SERUM PROTEIN LEVELS AFTER DISCHARGE}

DISCHARGE

FOLLOW-UP

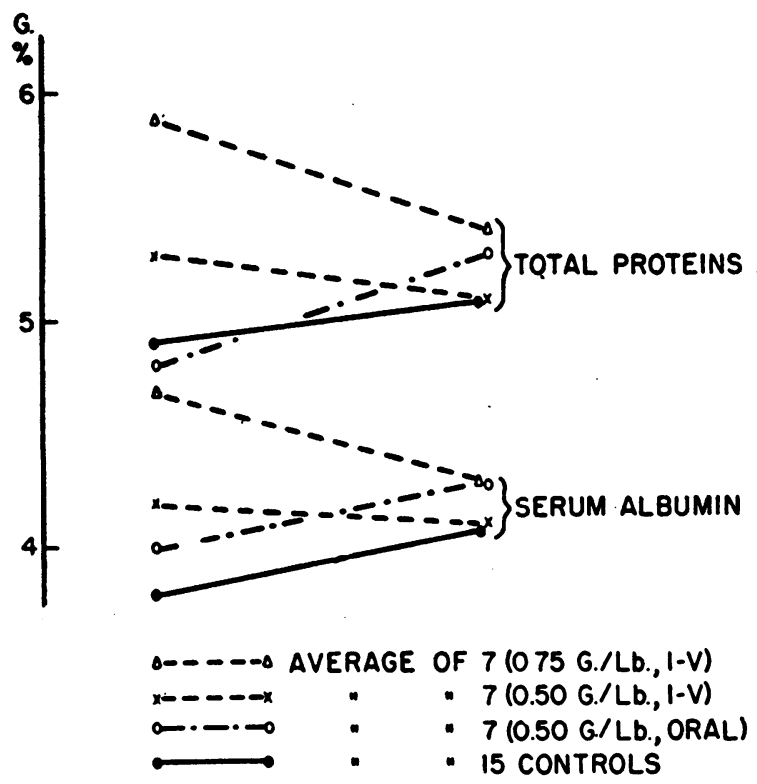

Fig. 3. Comparison of Serum Total Protein and Albumin Concentrations at Discharge and Three WeEks LATER

Dosage and route of albumin administered before discharge indicated at bottom of the figure.

small that the only observation justifiable is that the albumin offered no apparent protection against complications.

\section{Fate of albumin administered to premature infants}

The amounts of albumin experimentally administered to these patients were relatively considerable. Even the smaller intravenous dose would be equivalent, in an adult, to the injection of 150 G. of albumin weekly, or of the albumin in somewhat more than 3 liters of plasma, and, if the comparison be fully stated, continuing to do so for four to eight weeks or even longer. Since so little effect seemed to have resulted, the question arises, "Where does the albumin go?"

No renal loss of albumin was demonstrated in the urine. The per cent of change in hematocrit values following single injections of concentrated albumin solution to 11 individual infants is shown in Figure 4. Since no measurements of blood volume were made, the actual increase of plasma wa- ter brought about by these injections can only be roughly calculated on the assumption that original plasma volume equals 6 per cent of body weight. Such a calculation indicates that each gram of injected albumin caused from 8 to $21 \mathrm{cc}$. (average $15 \mathrm{cc}$.) of water to enter the vascular compartment during the first 15 minutes after administration. The average of $15 \mathrm{cc}$. may be compared with the published figure of $18 \mathrm{cc}$. of added fluid drawn into circulation per gram of injected albumin, predicted from osmotic pressure measurements (7) and obtained in investigations with adults in shock or after bleeding (8).

Figure 4 indicates that during five to six hours after injection of albumin the hematocrit readings, and thus presumably the plasma volumes, of most patients returned more or less completely to their pre-injection values. Unless unexpected change in number or volume of erythrocytes occurred, this implies a subsequent diffusion from the blood stream of the increased amount of plasma protein present there 15 minutes after administration. On the other hand, in those infants whose hematocrits remained at the low level, the albumin presumably continued to exert its osmotic effect in the vascular compartment at least for the interval covered by the diagram. Since we have been unable to correlate the individual differences portrayed in Figure 4 with maturity, age, hydration, or other characteristics of the few infants investigated in this way, we expect to study this aspect further in a larger series.

The daily nitrogen balances of nine infants before and after albumin administration were ascertained. In order to insure reasonably steady metabolic circumstances during the fore-periods, infants to whom albumin was being repeatedly fed or injected were not used for these studies. Diets of differing nitrogen content were fed to the individual infants so as to reveal any effect of alimentary protein level upon utilization of injected albumin. Because of physical difficulties imposed by continuous urine and stool collections in these small subjects, the balance periods following albumin administration were necessarily of only five to nine days duration. Although such periods were long enough to suggest the trend of albumin utilization, they were obviously insufficient for determining its complete disposition. The results are presented in Table IV and Figure 5. 


\section{CHANGE FROM ORIGINAL HEMATOCRIT VALUE}

IN ELEVEN INFANTS AFTER ALBUMIN INJECTION

(0.75 G: ALBUMIN / Lb.)

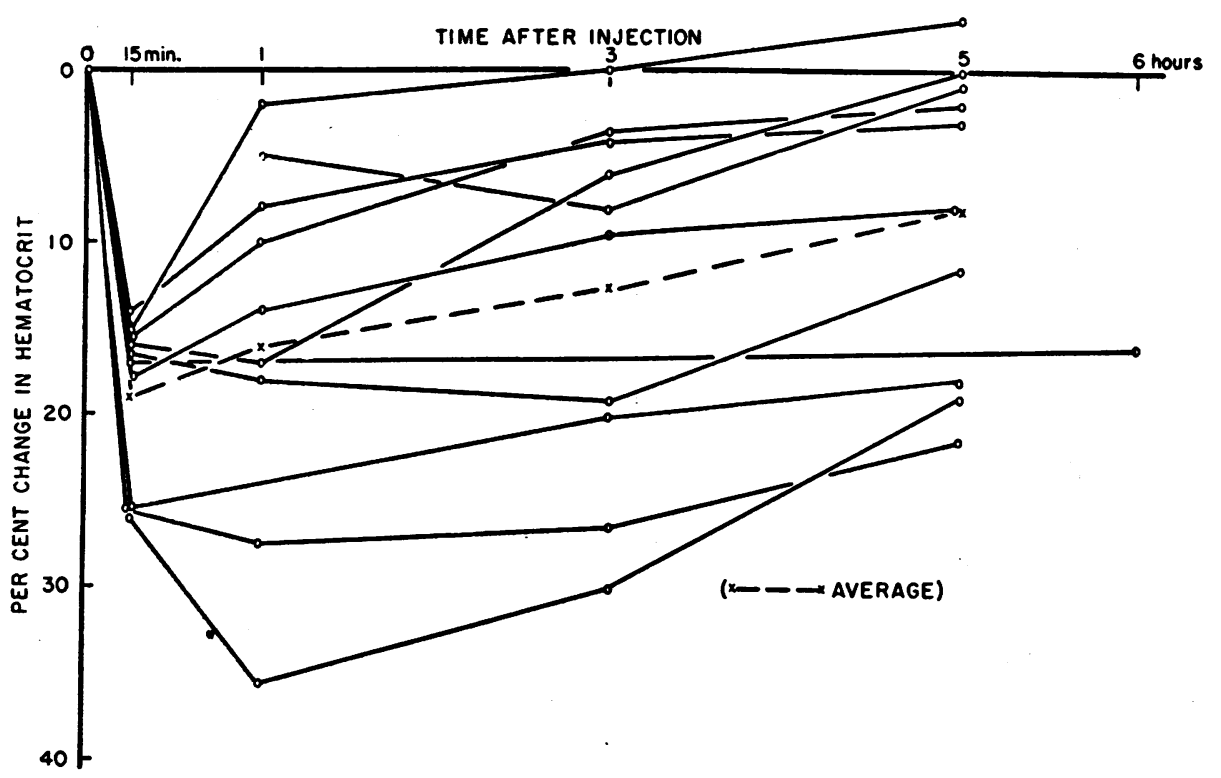

Fig. 4. Change in Hematocrit of 11 Premature Infants Following a Single Intravenous Injection of Concentrated Human Serum Albumin

In constructing Figure 5, the average daily nitrogen intake and utilization (per kilogram of body weight) were laid out as the unshaded areas, and nitrogen provided as albumin was then indicated by diagonal shading, the fraction retained being shown at the top of the after-period column, that excreted at the bottom.

Data from eight infants who received albumin by injection are arranged in Table IV and Fig- ure 5 in order of dietary protein intake. The first two infants (F. and B.) were furnished diets low in protein. They retained, respectively, 68 and 100 per cent of the albumin nitrogen during the brief periods after its injection. The three infants V., S., and A. received adequate though moderate dietary protein (human milk) and retained 30 to 52 per cent of the albumin nitrogen injected. Of the three infants on high protein diets (M., K.,

TABLE IV

Nitrogen balance studies

\begin{tabular}{|c|c|c|c|c|c|c|c|c|c|c|c|c|}
\hline \multirow{2}{*}{ Infant } & \multirow{2}{*}{ Age } & \multirow{2}{*}{ Weight } & \multicolumn{2}{|c|}{ Food/kg./day } & \multicolumn{2}{|c|}{$\begin{array}{c}\text { Aver. daily weight } \\
\text { gain (G.) }\end{array}$} & \multicolumn{2}{|c|}{ Length of periods } & \multirow{2}{*}{$\begin{array}{l}\text { Nitrogen given } \\
\text { as albumin }\end{array}$} & \multicolumn{3}{|c|}{ Retained } \\
\hline & & & Cals. & Nitrogen & $\begin{array}{c}\text { Fore- } \\
\text { period }\end{array}$ & $\begin{array}{l}\text { After- } \\
\text { period }\end{array}$ & $\begin{array}{l}\text { Fore- } \\
\text { period }\end{array}$ & $\begin{array}{l}\text { After- } \\
\text { period }\end{array}$ & & Diet & y $N$ & $\underset{\mathbf{N}}{\text { Albumin }}$ \\
\hline $\begin{array}{l}\text { F. } \\
\text { B. } \\
\text { V. } \\
\text { S. } \\
\text { A. } \\
\text { M. } \\
\text { K. } \\
\text { C. }\end{array}$ & $\begin{array}{l}\text { days } \\
29 \\
16 \\
17 \\
19 \\
37 \\
44 \\
22 \\
20\end{array}$ & $\begin{array}{l}\text { kg. } \\
1.67 \\
1.97 \\
1.98 \\
1.85 \\
1.6 \\
1.81 \\
2.21 \\
1.81\end{array}$ & $\begin{array}{l}156 \\
150 \\
143 \\
143 \\
144 \\
142 \\
144 \\
143\end{array}$ & $\begin{array}{c}G . \\
0.28 \\
0.32 \\
0.43 \\
0.45 \\
0.55 \\
1.00 \\
1.14 \\
1.36\end{array}$ & $\begin{array}{r}7.5 \\
7.5 \\
25.0 \\
28.0 \\
14.0 \\
38.0 \\
28.0 \\
26.0\end{array}$ & $\begin{array}{r}4.5 \\
4.5 \\
30.0 \\
34.0 \\
28.0 \\
43.0 \\
35.0 \\
41.0\end{array}$ & $\begin{array}{c}\text { days } \\
7 \\
7 \\
4 \\
3 \\
5 \\
3 \\
4 \\
4\end{array}$ & $\begin{array}{c}\text { days } \\
5 \\
5 \\
7 \\
6 \\
8 \\
6 \\
6 \\
8\end{array}$ & \begin{tabular}{l}
\multicolumn{1}{c}{ G./kg. } \\
0.52 (I.V.) \\
0.65 (I.V.) \\
0.26 (I.V.) \\
0.55 (I.V.) \\
0.6 (I.V.) \\
0.54 (I.V.) \\
0.54 (I.V.) \\
0.53 (I.V.)
\end{tabular} & $\begin{array}{l}\text { G./kg./ } \\
\text { day } \\
0.10 \\
0.23 \\
0.28 \\
0.29 \\
0.34 \\
0.64 \\
0.70 \\
0.64\end{array}$ & $\begin{array}{c}\text { per cent } \\
33 \\
64 \\
62 \\
65 \\
64 \\
61 \\
62 \\
44\end{array}$ & $\begin{array}{c}\text { per cent } \\
68 \\
100 \\
37 \\
52 \\
30 \\
0 \\
90 \\
29\end{array}$ \\
\hline G. & 33 & 2.15 & 143 & 1.07 & 28.0 & 41.0 & 5 & 9 & 0.8 (Oral) & 0.62 & 57 & 50 \\
\hline
\end{tabular}




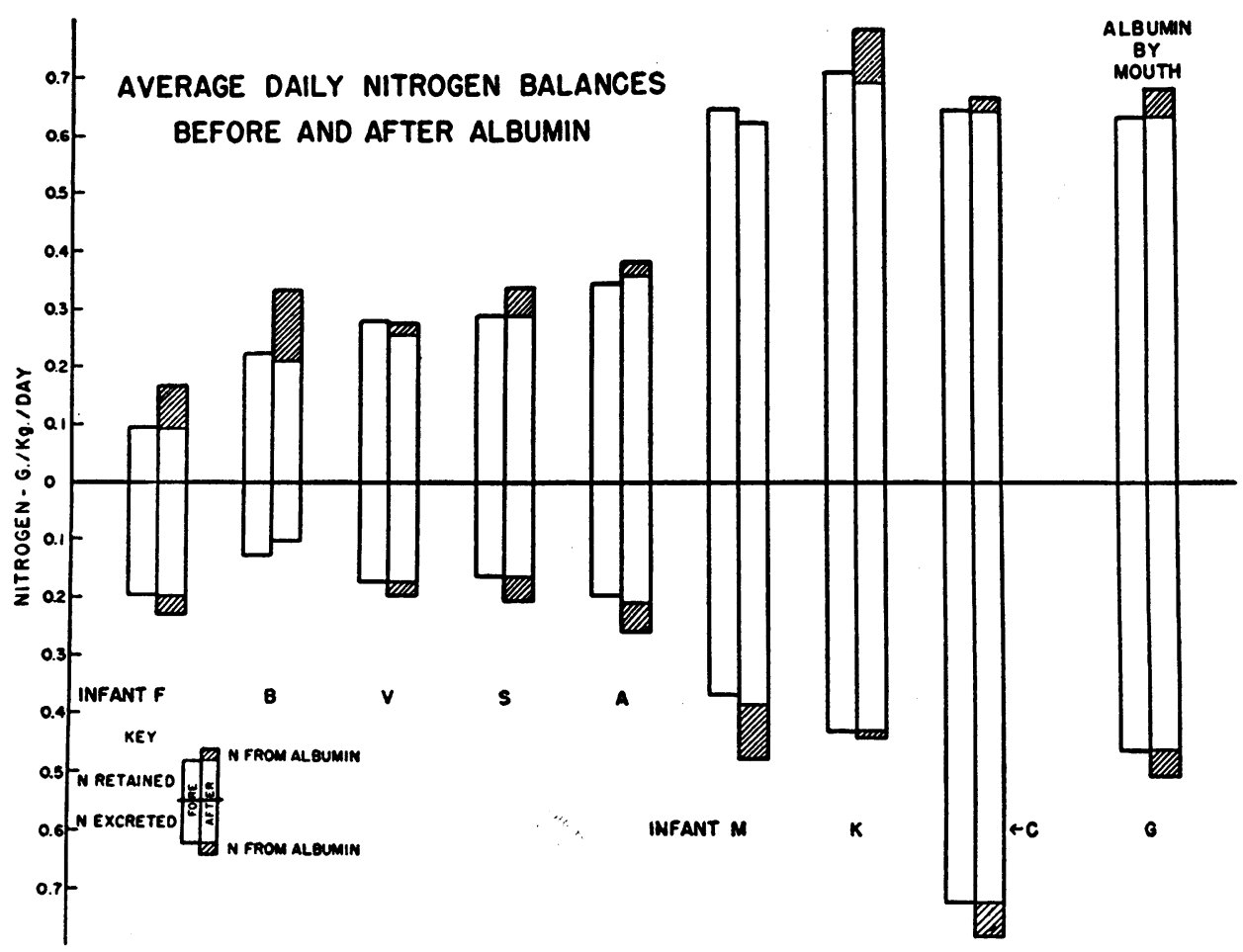

Fig. 5. Average Daily Nitrogen Balances of Nine Infants

See text and Table IV.

and $C_{\text {.) }}$, two (M. and C.) excreted all or most of that injected. Although there was one notable exception (Infant $K$.), the results suggest that if the infant's diet is at all adequate in protein, a considerable amount of injected albumin will not be retained but will be metabolized or, to use Albright's term (9) "burned," for energy and heat.

The retention of ingested albumin nitrogen was studied in only one infant, Baby G., described at the bottom of Table IV and at the extreme right of Figure 5. This baby was retaining about 57 per cent of the nitrogen in a rather high-protein feeding, and dealt with the addition supplied by albumin in almost exactly the same way, by retaining 50 per cent of it.

\section{DISCUSSION}

Studies on animals and on human adults (9, 10) have indicated that soon after the intravenous injection of albumin it diffuses throughout the entire extra-cellular compartment. An equilibrium is thus established within a matter of hours between the protein in the vascular and extra-vascular compartments. Presumably the albumin which has thus entered the interstitial fluids degenerates, though as to this we have no information except the rate of decay of that in the plasma. From such evidence it is thought that albumin reaching the interstitial fluid and bathing the cells is broken down (presumably to constituent amino acids) at a "50 per cent disappearance time" of four to six days (10). Part of the product of degeneration is then converted into various body proteins, while the rest is de-aminized for energy ("burned") with resultant excretion of non-protein nitrogen in the urine.

Premature infants offer interesting subjects for investigation of the fate of parenterally administered protein, since they normally display relatively low serum protein concentrations, inordinate growth, and large retentions of nitrogen from the diet. Thus, the average daily weight gain for 71 infants in the present study, once growth had begun, was $34 \mathrm{G}$., or about 2 per cent of the body weight, while retention of dietary nitrogen, as determined in nine infants, ranged from 33 to 65 per cent of intake. In spite of this combination of highly satisfactory metabolic attributes, the aver- 
age of serum protein levels for the control premature infants was just under $5 \mathrm{G}$., and of serum albumin $3.8 \mathrm{G} . / 100 \mathrm{cc}$. That these concentrations could be artificially raised by the repeated injection of human albumin has been demonstrated by McMurray, Roe, and Sweet (1), and by our own data. The elevations thus attained are not lasting, nor do they seem of large degree in view of the considerable amounts of injected albumin which produced them.

It appears that in these infants, as in the older patients discussed by Eckhardt and his colleagues (10), the bulk of the injected albumin must have disappeared from the blood stream fairly promptly, by diffusion and subsequent degradation. Otherwise a greater accumulation of serum albumin would have been produced during and after several weeks of injections repeated at three- or fourday intervals. It has been demonstrated (Table IV and Figure 5) that a variable portion of the resultant break-down product was utilized for energy and its nitrogen excreted in the urine. The amount used for this purpose seems to bear a rough relationship to the amount of protein in the diet. The nitrogen remaining in the body was presumably converted into body protein, including new molecules of serum albumin. The failure of these infants to divert more of the injected albumin nitrogen to the latter purpose may indicate a characteristic defect of the premature. Rimington and Bickford (2) showed that during intra-uterine life there is a steady rise in the protein content of the blood, and suggested that there may be a "fetal mechanism of synthesis of both albumin and globulin, which become relatively less important as the adult mechanisms of synthesis develop and take its place." Quantitative imperfections of fetal, as compared to adult, synthesis might thus account for the relatively low plasma protein levels after premature birth, and for the infant's inability to sustain higher levels even when the required nitrogen is made readily available.

But there remains another possibility. A major function of the plasma proteins is to provide sufficient intra-capillary osmotic pressure to overbalance hydrostatic pressures tending to force fluid out through the capillary walls. The lower the blood pressure within the capillaries, the lower will be the necessary opposing osmotic pressure to be supplied by the plasma proteins. Small animals with relatively low blood pressures and low intracapillary hydrostatic pressures require (and have) relatively low plasma protein concentrations (11). It is thus to be expected that in the premature infant, whose arterial blood pressure is some 60 or 70 per cent of the adult figure, physiological laws will be best satisfied if the plasma proteins are maintained at proportionately reduced levels. The temporary elevations of serum albumin which have been shown to follow repeated injections of concentrated albumin may thus be a distortion of circumstances entirely normal to premature infants. Moreover, these elevations may simply represent the introduction of albumin more rapidly than it can be degraded and its constituents converted to such body proteins as are required, or burned to provide energy. That this interpretation is correct is strongly suggested by the subsequent decline of artificially elevated serum protein levels to concentrations identical with those concurrently attained by the control group of infants.

\section{SUMMARY AND CONCLUSIONS}

Repeated intravenous injections of concentrated human serum albumin into 26 premature infants resulted in slightly higher levels of serum total proteins and albumin than in 27 control infants. Another group of 18 premature infants showed no significant effect of orally administered albumin upon serum protein or albumin levels. About three weeks after the cessation of treatment, serum total proteins and albumin had decreased in the injected infants and risen in the others, so that the measurements from all groups were practically identical.

No effect of albumin (injected or ingested) upon weight gain, hemoglobin concentration, erythrocyte count, or development of such complications as edema and infections, was noted.

Hematocrit changes gave evidence that each gram of injected albumin resulted in the addition of about $15 \mathrm{cc}$. of water to the plasma volume. In some infants this addition appeared to be sustained for six hours; in most, the hematocrit had returned to the original value within that time, indicating a return to original plasma volume.

Results of nine balance studies indicated that the nitrogen of human albumin, injected or fed to premature infants consuming usual diets, is only partially retained. If the diet is unusually low in pro- 
tein, more of the albumin nitrogen may be converted to body protein and less excreted.

In spite of the usually adequate supply of dietary nitrogen, the serum protein levels after premature birth are not sustained at concentrations normal to older children or adults, although a temporary elevation can be produced by repeated albumin injection. While this suggests a deficiency of synthesizing function, it may equally well be related to the lower capillary hydrostatic pressures and proportionately reduced requirement for colloid osmotic pressure in premature infants.

\section{ACKNOWLEDGMENTS}

The authors are grateful to Drs. Charles A. Janeway and Charles $\mathrm{S}$. Davidson for many suggestions.

Thanks are due to Miss Elsa Peterson and Miss Serene Berg for nursing assistance, and to Mrs. Clinton Piper for chemical analyses.

\section{BIBLIOGRAPHY}

1. McMurray, L.-G., Roe, J. H., and Sweet, L. K., Plasma protein studies on normal newborn and premature infants. I. Plasma protein values for normal full term and normal premature infants; II. Use of concentrated normal human serum albumin in treatment of premature infants. Am. J. Dis. Child., 1948, 75, 265.

2. Rimington, C., and Bickford, J. A., Pre- and post-natal development of immunity; serum-albumin and serum-globulin levels in maternal and cord bloods of premature infants. Lancet, 1947, 1, 781.
3. Lewis, J. H., and Wells, H. G., The function of the colostrum. J. A. M. A., 1922, 78, 863.

4. Rapoport, M., Rubin, M. I., and Chaffee, D., Fractionation of the serum and plasma proteins by salt precipitation in infants and children; the changes with maturity and age; the changes in glomerulonephritis; the changes in nephrosis. J. Clin. Invest., 1943, 22, 487.

5. Kingsley, G. R., Direct biuret method for determination of serum proteins as applied to photoelectric and visual colorimetry. J. Lab. \& Clin. Med., 1942, 27, 840.

6. Howe, P. E., The determination of proteins in blood; a micro-method. J. Biol. Chem., 1921, 49, 109.

7. Scatchard, G., Batchelder, A. C., and Brown, A., Chemical, clinical, and immunological studies on the products of human plasma fractionation. VI. The osmotic pressure of plasma and of serum albumin. J. Clin. Invest., 1944, 23, 458.

8. Heyl, J. T., Gibson, J. G., 2nd, and Janeway, C. A., Studies of the plasma proteins. V. The effect of concentrated solutions of human and bovine serum albumin on blood volume after acute blood loss in man. J. Clin. Invest., 1943, 22, 763.

9. Albright, F., Forbes, Anne P., and Reifenstein, E. C., The fate of plasma protein injected intravenously. Tr. A. Am. Physicianś, 1946, 59, 221.

10. Eckhardt, R. D., Lewis, J. H., Murphy, T. L., Batchelor, W. H., and Davidson, C. S., Chemical, clinical, and immunological studies on the products of human plasma fractionation. XXXIV. Comparative studies on the nutritive value of orally and intravenously administered human serum albumin in man. J. Clin. Invest., 1948, 27, 119.

11. Landis, E. M., Capillary pressure and capillary permeability. Physiol. Rev., 1934, 14, 404. 